\title{
PERILAKU ORGANISASI DI MASA PANDEMI COVID-19 (STUDI KASUS PERUSAHAAN ABC)
}

\author{
Dedi Rianto Rahadi \\ Fakultas Bisnis Jurusan Manajemen, President University \\ dedi1968@yahoo.com \\ Fauziah Rabbani \\ Fakultas Bisnis Jurusan Manajemen, President University \\ fauziahahwani@gmail.com \\ Fitri Choerunisa Fauzi \\ Fakultas Bisnis Jurusan Manajemen, President University \\ choerunisafitri7@gmail.com
}

Masuk : 29-03-2021, revisi : 12-04-2021, diterima untuk diterbitkan : 12-04-2021

\begin{abstract}
The existence of COVID-19 has had a changing impact on workers, workplaces, and work practices. Changes that arise in work practices include working from home and often using virtual, in interacting with fellow employees. ABC company is a company engaged in digital advertising (advertising) in Indonesia. In the research, an analysis of organizational behavior during the Covid-19 pandemic at ABC company will be presented. The research method used is descriptive qualitative. The results showed that there were four characteristics of corporate organizational culture seen in $\mathrm{ABC}$ company, namely the existence of risk-taking through WFH; company operations are disrupted due to additional time causing less smooth communication with clients; In the aspect of communication between leaders and employees, virtual communication facilities have been provided, although in practice there are still obstacles; teamwork was a little distracted by the time lag response in virtual communication.
\end{abstract} Keywords: Organizational Culture, COVID-19 Pandemic, Case Study

Abstrak: Adanya COVID-19 berdampak perubahan bagi pekerja, tempat kerja, dan praktik kerja. Perubahan yang muncul dalam praktik kerja diantaranya work from home dan seringkali menggunakan virtual, dalam berinteraksi sesama pegawai. Perusahaan ABC merupakan perusahaan yang bergerak di bidang periklanan digital (advertising) di Indonesia. Dalam penelitian, akan disajikan analisis perilaku organisasi selama pandemi COVID-19 di perusahaan ABC. Metode penelitian menggunakan deskriptif kualitatif. Hasil penelitian memperlihatkan terdapat empat karakteristik budaya organisasi perusahaan yang terlihat pada perusahaan $\mathrm{ABC}$, yaitu adanya pengambilan risiko melalui $\mathrm{WFH}$; operasional perusahaan terganggu karena ada waktu tambahan menyebabkan kurang lancarnya komunikasi dengan klien; pada aspek komunikasi antara pimpinan dengan karyawan telah disediakan fasilitas komunikasi virtual, walaupun dalam prakteknya masih terdapat kendala; kerja tim sedikit terganggu karena adanya respon jeda waktu dalam komunikasi virtual.

Kata Kunci: Perilaku Organisasi, Pandemi COVID-19, Studi Kasus

\section{PENDAHULUAN}

COVID-19 adalah krisis kesehatan global dan ancaman ekonomi internasional. Penguncian bisnis dan industri di seluruh dunia yang diterapkan dan diamanatkan untuk mengekang penyebaran virus menghasilkan beragam tantangan unik dan mendasar bagi karyawan dan pemberi kerja di seluruh dunia. Pada tingkat individu, populasi karyawan yang terkena dampak pemutusan hubungan kerja diubah dalam semalam menjadi (a) karyawan 
"bekerja dari rumah", (b) pekerja "penting” atau "penopang hidup" (misalnya personel medis ruang gawat darurat dan staf supermarket), atau (c) karyawan yang diberhentikan atau diberhentikan mencari tunjangan pengangguran yang setara dengan negara tertentu. Secara organisasi, penghentian ekonomi dan kegiatan pemerintah terkait tampaknya cenderung (i) mengubah beberapa industri secara fundamental, (ii) mempercepat tren yang sudah berlangsung di industri lain, dan (iii) membuka peluang munculnya industri baru, seperti yang biasanya terjadi pada saat perang dan bencana alam (Sine \& David, 2003). Mengingat ketidakpastian dan luasnya guncangan COVID-19, sisi psikologis kerja dan organisasi sangat perlu menerapkan pengetahuan lapangan saat ini untuk tujuan untuk membantu individu dan organisasi mengelola risiko sambil mengembangkan dan menerapkan solusi.

Perusahaan $\mathrm{ABC}$ adalah sebuah perusahaan yang bergerak dibidang advertising (periklanan) digital di Indonesia. Perusahaan ini beroperasi sejak tahun 2015. Memiliki pengalaman dengan mengerjakan projek iklan digital lebih dari 100 klien. Perusahaan ABC memiliki pekerja sebanyak 30 orang. Sebelum pandemi sistem kerja yang dilakukan adalah klien bertemu dengan tim kreatif dari perusahaan. Lalu klien menyampaian maksut dan gambaran umum iklan yang akan dibuat. Setelah itu tim kreatif akan membuat konsep detail dari iklan dan menyerahkan ke tim teknis disain digital. Selanjutnya tim digital akan memvisualisasikan iklan dalam bentuk digital. Dan setelah selesai, hasil akan dipresentasikan di depan klien. Perilaku organisasi khususnya dalam hal proses pebuatan iklan digital dilakukan di workshop yang tersedia di gedung perusahaan ABC. Namun dengan adanya pandemi ini, perilaku kerja organisasi perusahaan $\mathrm{ABC}$ mengalami perubahan yang siginifikan. Khususnya pada proses pertemuan dengan klien dan saat produksi iklan digital. Dari uraian diatas rumusan masalah yang diajukan adalah bagaimana analisis perilaku organisasi di masa pandemi COVID-19 pada perusahaan ABC.

\section{TELAAH KEPUSTAKAAN}

Perilaku organisasi merupakan: "Studi tentang perilaku manusia dalam pengaturan organisasi, antarmuka antara perilaku manusia dan konteks organisasi, dan organisasi itu sendiri”. Definisi di atas memiliki tiga aspek - perilaku individu, organisasi, dan interaksi di antara keduanya. Setiap individu membawa ke sebuah organisasi seperangkat keyakinan, nilai, sikap dan karakteristik pribadi lainnya yang unik dan karakteristik dari semua individu ini harus berinteraksi satu sama lain untuk membuat pengaturan organisasi. Perilaku organisasi secara khusus berkaitan dengan perilaku terkait pekerjaan yang terjadi dalam organisasi (Saravanakumar, 2019). Seperti telah disebutkan dalam latar belakang bahwa perubahan yang muncul dalam praktik kerja selama pandemi, berupa wajib bekerja dari rumah, lingkungan virtual, dalam skala yang belum pernah terjadi sebelumnya (Kniffin et al., 2021).

Bekerja dari rumah (WFH) dimaksudkan sebagai cara bekerja dalam sebuah organisasi yang dilaksanakan sebagian atau seluruhnya di luar kantor konvensional dengan bantuan layanan telekomunikasi dan informasi (DeRosa et al., 2007). Pengamatan sekilas menunjukkan bahwa pemahaman bekerja jarak jauh setidaknya menyangkut 4 (empat) hal yaitu (Mungkasa, 2020):

a. Pilihan tempat kerja, yang mengacu pada penghematan waktu/jarak fisik (tele).

b. Sebagian atau substitusi total dari penglaju (commute) harian.

c. Intensitas aktivitas bekerja jarak jauh, yang mengacu pada kekerapan dan lamanya waktu.

d. Ketersediaan teknologi komunikasi dan informasi.

Sebelum pandemi, tim virtual semakin bertambah dan semakin penting (Mak \& Kozlowski, 2019). Alih-alih mengasumsikan keseragaman dalam karakteristik tim virtual, penting untuk diketahui bahwa "virtualitas tim" adalah konsep multi-faktor dan mencakup beberapa dimensi termasuk distribusi geografis anggota tim dan sebuah komunikasi elektronik yang sinkron (Hoch \& Kozlowski, 2014). Penelitian sebelumnya menunjukkan bahwa kerja 
tim virtual cenderung kurang kaya komunikasi yang tersedia untuk tim tatap muka (Martins et al., 2004) dan bahwa masalah kerja tim tradisional seperti konflik dan koordinasi dapat meningkat dengan cepat dalam tim virtual (Mortensen \& Hinds, 2001). Membangun perancah struktural untuk mengurangi konflik, menyelaraskan tim, dan memastikan pemrosesan informasi yang aman dan menyeluruh adalah rekomendasi utama untuk tim virtual. Misalnya, pekerjaan sebelumnya telah menunjukkan kebutuhan - terutama dalam tim virtual - untuk memformalkan proses tim, memperjelas tujuan tim, dan membangun solusi struktural untuk mendorong diskusi yang aman secara psikologis (Gibson \& Gibbs, 2006).

Istilah kepemimpinan dan manajemen virtual diperkenalkan oleh Avolio et al. (2000) melalui artikel ilmiah berjudul E-leadership: Implications for Theory, Research, and Practice. Menurut Avolio et.al (2000), e-leadership dikerjakan di lingkungan teknologi melalui internet. Jadi, e-leadership sekaligus berfungsi untuk komunikasi, pengumpulan dan penyebaran informasi. Pemimpinnya disebut e-leader atau pemimpin virtual, dan pendekatan kepemimpinannya disebut e-leadership atau virtual leadership (Munir, 2020). Pemimpin virtual mengarahkan anak buah dari jarak jauh secara maya, menggunakan teknologi baru untuk meningkatkan pekerjaan mereka, untuk menemukan model bisnis baru, untuk berkomunikasi dengan pengikut mereka. Interaksi tatap muka tradisional telah diganti dengan media elektronik, terutama melalui internet. Pemimpin virtual harus berkomunikasi dengan orang-orang melalui media elektronik secara efektif (Munir, 2020). Pemimpin virtual harus berusaha keras mengarahkan dan membimbing orang-orang dari jarak jauh. Jadi, pemimpin virtual harus menciptakan tantangan besar untuk menciptakan budaya virtual kolaboratif, yaitu budaya berkoordinasi untuk mencapai tujuan bersama, membangun iklim sosial melalui teknologi informatika (Munir, 2020).

Penelitian tentang keefektifan pemimpin selama dan setelah krisis COVID-19 harus memeriksa serangkaian kegiatan, termasuk sejauh mana pemimpin jarak jauh bersikap persuasif jika:

a. menyatakan dengan jelas nilai-nilai mereka yang akan memandu tindakan kelembagaan.

b. memahami dan secara terbuka mendiskusikan kesulitan dan harapan organisasi mereka.

c. dengan jelas mengkomunikasikan visi ambisius tentang arah yang akan dituju unit.

d. menunjukkan keyakinan bahwa tujuan strategis dapat dicapai.

Keterampilan ini disebut sebagai karisma dan membutuhkan pelatihan dan investasi (Grabo \& Vugt, 2016). Memang, krisis dapat membawa perubahan dalam gaya kepemimpinan (Stoker et al., 2021); dengan demikian, perusahaan dapat berharap untuk menjadi lebih siap dengan memastikan mereka telah berinvestasi secara memadai dalam pengembangan profesional. Dalam hal ini, penelitian di masa depan harus memperkirakan apakah dan bagaimana komitmen organisasi terhadap pengembangan profesional karyawan selama krisis COVID-19 dapat menghasilkan dividen nanti.

\section{METODE PENELITIAN}

Pendekatan deskriptif kualitatif digunakan sebagai metode dengana memanfaatkan data kualitatif kemudian dideskripsikan untuk menganalisis suatu peristiwa atau keadaan secara sosial (Moleong, 2017). Informan dalam penelitian ini terdiri dari dua karyawan dan satu orang manager di perusahaan ABC. Adapun pertanyaan yang akan diajukan dengan mengunakan pendapat perubahan yang muncul dalam praktek kerja oleh Kniffin et al. (2021): 
Tabel 1

Daftar Pertanyaan Penelitian

\begin{tabular}{|c|l|}
\hline Informan & \multicolumn{1}{c|}{ Pertanyaan } \\
\hline \multirow{5}{*}{ Manager } & $\begin{array}{l}\text { Bagaimana kebijakan WFH mempengaruhi sikap dan perilaku karyawan terhadap klien } \\
\text { dan juga rekan kerja mereka? }\end{array}$ \\
\cline { 2 - 3 } & $\begin{array}{l}\text { Faktor-faktor apa yang akan menyebabkan perilaku membantu dan prososial dalam tim } \\
\text { dengan tingkat virtualitas rendah atau tinggi - dan bagaimana ini akan berdampak pada } \\
\text { hasil kerja karyawan? }\end{array}$ \\
\cline { 2 - 3 } & $\begin{array}{l}\text { Bagaimana pimpinan perusahaan menyesuaikan gaya mereka dalam menanggapi } \\
\text { kondisi seperti pandemi saat ini? }\end{array}$ \\
\hline \multirow{5}{*}{ Karyawan } & $\begin{array}{l}\text { Bagaimana kebijakan WFH mempengaruhi sikap dan perilaku saudara sebagai } \\
\text { karyawan terhadap pimpinan dan juga rekan kerja? }\end{array}$ \\
\cline { 2 - 2 } & $\begin{array}{l}\text { Faktor-faktor apa yang akan menyebabkan perilaku membantu dan prososial dalam tim } \\
\text { dengan tingkat virtualitas rendah atau tinggi - dan bagaimana ini akan berdampak pada } \\
\text { hasil kerja saudara? }\end{array}$ \\
\cline { 2 - 2 } & $\begin{array}{l}\text { Bagaimana saudara akan menyesuaikan diri dalam menanggapi kondisi seperti pandemi } \\
\text { saat ini? }\end{array}$ \\
\hline
\end{tabular}

\section{HASIL DAN KESIMPULAN}

Dari pertanyaan tentang WFH yang menpengaruhi sikap dan perilaku karyawan, manager menyatakan bahwa karyawan yang semula dapat berinteraksi secara fisik dengan klien namun saat ini tidak sepenuhnya dapat terjadi. Pertemuan fisik tetap dilakukan dengan tetap menjalankan protokol kesehatan. Namun pada sebagian besar waktu pertemuan dilakukan secara virtual dari rumah. Terdapat beberapa kendala diantaranya adalah saat berdiskusi soal ide iklan. Pada sebelum pandemi, diskusi juga menggunakan "papan tulis" guna menyampaikan ide dan rancangan iklan. Dan pada saat yang bersamaan, klien bisa langsung mengkoreksi baik itu dengan "mencoret" langsung di papan tulis atau disampaikan secara lisan. Namun dengan WFH media papan tulis menjadi sulit dilakukan. Sedangkan untuk tim kerja, dinyatakan bahwa tidak menemui kendala yang berarti dalam hal komunikasi. Namun terkendala dalam hal pengerjaan iklan digital dikarenakan karaywan yang WFH belum tentu memiliki perangkat komputer yang memadai di rumahnya. Jadi pengerjaan akan sedikit melambat karena karaywan mengerjakan dirumah dalam hal yang umum lalu di "finishing" dikantor.

Dari pertanyan tentang sikap karyawan terhadap provasi dan pemantauan kinerja, manager menyatakan privasi tidak ada yang berbeda saat WFH atau dikantor, dikarenakan setiap karyawan memiliki area kerja dan perangkat masing-masing. Dan pemantauan kinerja juga tidak mengalami kendala. Perusahaan tidak melihat proses yang dilakukan karyawan, yang dilihat adalah waktu penyelesaian dan keseuaian isi projek yang dikerjakan. Dari sisi karyawan disebutkan bahwa privasi antara WFH dan di kantor terlihat sedikit perbedaan privasi yang lebih menguntungkan karyawan adalah karyawan tidak perlu terlalu "kaku" dalam bekerja. Misalnya karyawan tidak perlu memakai pakain resmi, bekerja sambil merokok hingga mengerjakan denga aturan jadwal sendiri. Dari sisi pemantauan disebutkan bahwa karyawan tidak melihat ada kendala yang berarti. Karena sesuai informan sebelumnya, kinerja yang diukur adalah waktu dan kesesuaian iklan yang dikerjakan.

Dari pernyataan tentang ekspresi komunikasi, manager mengatakan dengan virtualitas rendah (bekerja di kantor) komunikasi berjalan lebih cepat. Namun jika virtualitas tinggi terdapat kendala sinyal dan membutuhkan waktu yang lebih untuk menyamakan persepsi baik itu dengan klien atau rekan kerja. Dari sisi karyawan menyatakan, bahwa virtualitas rendah memiliki komunikasi yang lebih efektif. Namun hal ini mungkin dikarenakan karyawan belum terbiasa dengan virtualitas tinggi.

Dari pertanyaan tentang penyesuaian pimpinan perusahaan, manager menyatakan bahwa pimpinan mengalami sedikit kendala khususnya dalam hal motivasi dan koreksi kinerja karyawan. Melalui virtual, pimpinan tidak bisa dengan cepat membangun "chemistry" yang 
kuat dengan para karyawan. Dari aspek karyawan, dinyatakan bahwa karyawan cenderung merasa bekerja sendiri dibandingkan bekerja secara tim. Dikarenakan arahan dari pimpinan yang tidak selalu tersampaikan secara penuh. Hal ini dikarenakan waktu komunikasi yang terbatas karena melalui media telekomunikasi di jadwal tertentu. Adapun arahan memalui "titip pesan" kadang tidak langsung dibaca saat arahan itu masuk.

Kemampuan untuk tetap bertahan (survival skill) karakteristik budaya organisasi perusahaan menjadi pedoman dalam setiap aktifitas. Ada empat karakteristik budaya organisasi perusahaan yang dapat menjadi indikator dalam menganalisis perusahaan pada saat menghadapi COVID-19 (Rosdiana, 2020):

1. Adanya Inovasi dan Pengambilan Resiko. Bersikap selalu inovatif dan bereksperimen dalam bekerja khususnya terutama pada penyelesaian masalah yang timbul di masa pandemi ini. Dalam pelaksanaannya, perusahaan $\mathrm{ABC}$ telah mengutamakan keselamatan semua pihak baik itu perusahaan serta klien melalui ketaatan menjalankan aturan pemerintah yaitu WFH. Dalam hal pemantauan kinerja karyawan diluar lingkungan kantor, perusahaan $\mathrm{ABC}$ tidak membuat langkah inovasi dikarenakan pada sistem terdahulu kinerja dilihat dari hasil dan isi projeknya.

2. Memperhatikan Secara Mendetail. Karakteristik budaya organisasi perusahaan menuntut agar anggota organisasi diminta fokus dan cermat dalam bekerja serta ketepatan dalam menganalisis hasil pekerjaan. Di perusahaan ABC, detail adalah salah satu keunggulan perusahaan. Namun proses detail sedikit terganggu karena adanya waktu ekstra dikarenakan komunikasi dengan klien kurang berjalan mulus.

Dari hasil wawancara setidaknya dapat disimpulkan bahwa terdapat empat dimensi penilaian perilaku perusahan yang terjadi di masa pandemi.

1. Adanya Inovasi dan Pengambilan Resiko. Dalam pelaksanaannya, perusahaan ABC telah mengutamakan keselamatan semua pihak baik itu perusahaan serta klien melalui ketaatan menjalankan aturan pemerintah yaitu WFH.

2. Memperhatikan Secara Mendetail. Di perusahaan ABC, detail adalah salah satu keunggulan perusahaan. Namun proses detail sedikit terganggu karena adanya waktu ekstra dikarenakan komunikasi dengan klien kurang berjalan mulus.

3. Berorientasi Pada Kebermanfaatan. Orientasi kesehatan karyawan dan klien sudah menjadi perhatian utama saat pendemi ini. Dalam aspek komunikasi antar pimpinan dengan karyawan telah diberikan sarana komunikasi virtual. Walau dalam pelaksanaannya masih mengalami kendala.

\section{DAFTAR PUSTAKA}

Avolio, B. J., Kahai, S., \& Dodge, G. E. (2000). E-leadership: Implications for theory, research, and practice. Leadership Quarterly, 11(4), 615-668. https://doi.org/10.1016/s1048-9843(00)00062-x

DeRosa, D. M., Smith, C. L., \& Hantula, D. A. (2007). The medium matters: Mining the long-promised merit of group interaction in creative idea generation tasks in a metaanalysis of the electronic group brainstorming literature. Computers in Human Behavior, 23(3), 1549-1581. https://doi.org/10.1016/j.chb.2005.07.003

Gibson, C. B., \& Gibbs, J. L. (2006). Unpacking the concept of virtuality: The effects of geographic dispersion, electronic dependence, dynamic structure, and national diversity on team innovation. Administrative Science Quarterly, 51(3), 451-495. https://doi.org/10.2189/asqu.51.3.451

Grabo, A., \& Vugt, M. van. (2016). Charismatic leadership and the evolution of cooperation. Evolution and Human Behavior, 37(5), 399-406. https://doi.org/10.1016/j.evolhumbehav.2016.03.005 
Hoch, J. E., \& Kozlowski, S. W. J. (2014). Leading virtual teams: Hierarchical leadership, structural supports, and shared team leadership. Journal of Applied Psychology, 99(3), 390-403. https://doi.org/10.1037/a0030264

Kniffin, K. M., Narayanan, J., Anseel, F., Antonakis, J., Ashford, S. P., Bakker, A. B., Bamberger, P., Bapuji, H., Bhave, D. P., Choi, V. K., Creary, S. J., Demerouti, E., Flynn, F. J., Gelfand, M. J., Greer, L. L., Johns, G., Kesebir, S., Klein, P. G., Lee, S. Y., ... Vugt, M. van. (2021). COVID-19 and the workplace: Implications, issues, and insights for future research and action. American Psychologist, 76(1), 63-77. https://doi.org/10.1037/amp0000716

Mak, S., \& Kozlowski, S. W. J. (2019). Virtual teams: Conceptualization integrative review and research recommendations. In R. N. Landers (Ed.), The Cambridge Handbook of Technology and Employee Behavior (pp. 441-479). Cambridge University Press. https://doi.org/10.1017/9781108649636.018

Martins, L. L., Gilson, L. L., \& Maynard, M. T. (2004). Virtual teams: What do we know and where do we go from here? Journal of Management, 30(6), 805-835. https://doi.org/10.1016/j.jm.2004.05.002

Moleong, L. J. (2017). Metodologi penelitian kualitatif (Revisi). Penerbit Rosda.

Mortensen, M., \& Hinds, P. J. (2001). Conflict and shared identity in geographically distributed teams. International Journal of Conflict Management, 12(3), 212-238. https://doi.org/10.1108/eb022856

Mungkasa, O. (2020). Bekerja dari rumah (Working from home/WFH): Menuju tatanan baru era pandemi COVID-19. Jurnal Perencanaan Pembangunan: The Indonesian Journal of Development Planning, 4(2), 126-150. https://doi.org/10.36574/jpp.v4i2.119

Munir, N. S. (2020). Kepemimpinan di era digital (e-Leadership). SWA.Co.Id. https://swa.co.id/swa/my-article/kepemimpinan-di-era-digital-e-leadership

Rosdiana, Y. (2020). Dampak Covid-19 terhadap budaya organisasi perusahaan. AyoSemarang.Com. https://semarang.ayoindonesia.com/netizen/pr-77791052/DampakCovid19-Terhadap-Budaya-Organisasi-Perusahaan?page=all

Saravanakumar, A. (2019). Unit 1 organizational behaviour. In Organizational Behaviour. Alagappa university SIM Mode Book.

Sine, W. D., \& David, R. J. (2003). Environmental jolts, institutional change, and the creation of entrepreneurial opportunity in the US electric power industry. Research Policy, 32(2 SPEC.), 185-207. https://doi.org/10.1016/S0048-7333(02)00096-3

Stoker, J. I., Garretsen, H., \& Lammers, J. (2021). Leading and working from home in times of COVID-19: On the perceived changes in leadership behaviors. Journal of Leadership and Organizational Studies, 37(5), 1-11. https://doi.org/10.1177/15480518211007452 